\section{Bending Reality: Adventures in Global Plastic Surgery}

Author: Richard C Schultz

Print length: 243 pages ( 87 illustrations)

Publisher: Bookstand Publishing

Publication date: December 12, 2013

ISBN-10: 1618635549

Dr. Schultz, former head of Plastic Surgery, and now Emeritus Professor at The University of Illinois (CA), has written a memoir of his 37 years of a rather colorful career advancing modern concepts in reconstructive plastic surgery, (i.e., new concepts in post traumatic facial reconstruction, cleft palate repair, etc.) around the world. These activities often put him in disadvantaged African, Asian and East European Communist countries, sometimes culminating in life threatening events. While serving as a Fulbright scholar with Prof. Tord Skoog in Uppsala, Sweden in 1960, he was recruited by the Central Intelligence Agency (CIA) to observe communist connections in this socialist country. This led to a visit with the Surgeon General of The Soviet Army who was advocating a secret but ineffective method of treating 3rd degree thermal burns in soldiers, attempting to hasten their return to duty.

Schultz describes two potentially dangerous encounters with the Chicago underworld involving plastic surgery, along with a night spent in jail over conflicting ethical responsibilities.

His four books, numerous journal publications, and leadership positions in multiple professional societies served to attract foreign plas-

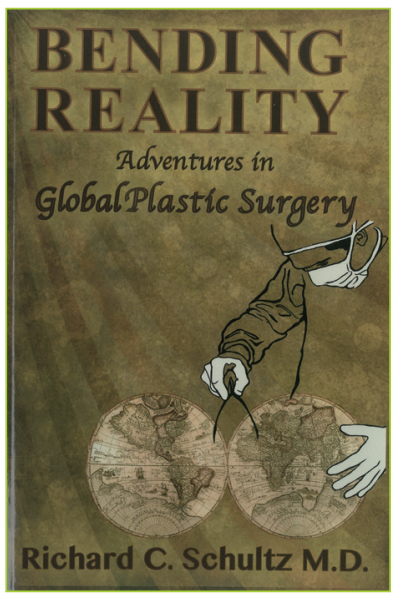

tic surgeons to visit him in Chicago. Among these were Ivo Pitanguy (Brazil), Paul Tessier and Yves Gerard Illouz (France), Bong Soo Baik (South Korea), Namik Baron (Turkey), as well as numerous German and Japanese maxillofacial surgeons, many of whom stayed in his home and, on occasion, were taken to his summer home in Michigan.

Illustrations of a variety of surgical procedures performed by the author, including his approach and involvement in separation of craniopagus twins, significantly enhance the text.

Correspondence: Richard C Schultz

Department of Surgery, College of Medicine, University of Illinois, Chicago, P.0. Box 357, Northport, MI, USA

Tel: +1-231-386-5950,E-mail: schultz5@coslink.net

No potential conflict of interest relevant to this article was reported.

Received: 14 Aug 2014 • Revised: 19 Aug 2014• Accepted: 19 Aug 2014 pISSN: 2234-6163 • elSSN: 2234-6171

http://dx.doi.org/10.5999/aps.2015.42.1.84 • Arch Plast Surg 2015;42:84 